\title{
HISTORIA DO PODER, HISTÓRIA POLÍTICA
}

Ciro Flamarion Cardoso*

\section{1 - "DESCONSTRUÇÃO" DA HISTÓRIA POLÍTICA?}

Tomemos como ponto de partida certas idéias de Marc Augé, antropólogo francês, sobre o mundo da atualidade.

Quanto ao tempo, mudou a nossa percepção dele, mas também o que com ele fazemos (como dele dispomos). O tempo, hoje, deixou de ser um princípio de inteligibilidade, com a crise da noção de progresso e portanto da história com sentido, evolutiva. Paralelamente, nota-se o interessse crescente por temáticas antropológicas como a família, a vida privada, os "lugares da memória", a análise micro ou em pequena escala das sociedades. Constata-se uma perda das identidades: o que se busca hoje nos "lugares da memória" são signos visiveis do que costumávamos ser, é tentar descobrir o que somos pela constatação do contraste com o que já não somos; como se se almejasse um lampejo de revelação indicador de uma identidade que não achamos, para tornar manejável nossa relação com um mundo que, movendo-se rapidamente demais, nos faz perder os pontos de referência. Neste ponto, Augé dialoga com Pierre Nora.

A proposta de nosso antropólogo, a respeito, é de examinar o tempo, não do ponto de vista habitual da erosão da noção de progresso pelas atrocidades do século XX - queremos dizer: habitual para o chamado pós-modernismo -, mas sim, a partir da noção de que ocorreu uma aceleração da história. O passado se torna história, em nosso século, a um ritmo alucinante: a história

* Professor no Curso de Pós-Graduação em História da Universidade Federal Fluminense.

Estudos Ibero-Americanos. PUCRS, v. XXIII, n. 1, p. 123-141, junho, 1997 
corre atrás de nós, está em nossos calcanhares. Por história, Augé entende os eventos ou séries de eventos que numerosas pessoas reconhecem como tal: os Beatles, 1968, a Argélia, o Vietnã, o muro de Berlim, a guerra do Golfo, a desintegração da União Soviética... Há uma superabundância de eventos considerados relevantes, de que somos informados simultaneamente a seu acontecimento, acumulando-se em ritmo rápido demais para sua assimilação ou sua consideração em perspectiva.

Ora, constata-se que, em geral, tais eventos que parecem capitais não foram previstos por economistas, historiadores ou sociólogos. A superabundância daqueles eventos vem não somente de uma informação superabundante, mas também da crescente interdependência presente no interior do que já se configura como um "sistema mundial". O resultado do conseqüente desnorteamento é uma forte necessidade de achar sentido para um presente que parece imprevisível, estranho, inexplicável: "outro", portanto. Daí um excesso de investimento no sentido, ou mais exatamente na busca do sentido.

A superabundância do tempo do mundo e também dos indivíduos (no mundo desenvolvido não mais três, e sim, quatro gerações coexistem) é uma das características daquilo que Augé chama de Supermodernidade.

No tocante ao espaço, teríamos uma situação paradoxal. A Terra é vista do espaço como pequena bola colorida: algo distante, insignificante. Ao mesmo tempo, porém, o nosso mundo - tornado pequeno pelas comunicações instantâneas e pelos transportes rápidos - é superabundante em espaço, posto que todo o espaço do planeta está virtualmente aberto às pessoas. A supermodernidade torna difícil a apreensão do espaço por tal superabundância. Nele, os pontos de referência culturais não deixam de existir; mas o espaço se complica e se relativiza. Também aqui surge a estranheza, aparece a alteridade, mesmo porque ainda não conhecemos bem a dialética globalidade/ particularismos, nem a organização espacial específica da supermodernidade (domínio em que, precisamente, Augé oferece suas hipóteses principais).

Por fim, no que diz respeito ao ego, à individualidade, de novo achamos o excesso que define a supermodernidade. Nas sociedades ocidentais, o indivíduo quer ser um mundo em si mesmo, interpretar a informação a que tem acesso por si e para si mesmo. Isto leva por força a uma crença no valor absoluto do indivíduo, seus direitos, suas expectativas; e na necessária multiplicação dos enfoques. Tal situação, entretanto, se explica na verdade por um desnorteamento dos indivíduos no mundo de hoje, acelerado em suas transformações: vêem-se afetados por elas, num momento em que os ele- 
mentos de identificação coletiva disponíveis para o indivíduo estão mais enfraquecidos do que nunca estiveram no passado (por exemplo: família, nação, ideologias). Existe a necessidade urgente de uma produção individual de significações. A qual ocorre, claro, sob a influência de um aparelho multifacético de publicidade e de propaganda política que se adapta bem ao individualismo extremado de hoje: a publicidade fala do corpo, dos sentidos, da vida sadia; os políticos, das liberdades individuais.

Poder-se-ia dizer, em suma, que a supermodernidade se caracteriza por aparentes paradoxos. De um lado temos processos de inter-relação, globalização, aceleração, destruição das construções espaciais habituais. De outro, percebe-se forte ênfase na individualização das referências: singularidade dos objetos, dos grupos e associações etc.

Para Augé, os três traços apontados - superabundância dos eventos no tempo, superabundância do espaço e individualização das referências tornam possível falar da supermodernidade sem esquecer suas complexidades e contradições, já que ela, mais que por destruir, caracteriza-se por acumular componentes, uns ao lado dos outros. ${ }^{1}$

O ponto de partida de Augé em suas ruminações sobre o mundo de nossos dias parece ser um famoso artigo de Pierre Nora, incluído na coletânea Faire de l'histoire, no volume I sobre Novos problemas - artigo intitulado "A volta do evento". Ora, também Nora, no artigo em questão, se restringia à análise das perspectivas da história do presente: um presente em que os meios de comunicação de massa "democratizam" o evento - isto é, tornam-no imediatamente acessível a milhões de pessoas - mas, ao mesmo tempo, o produzem, metamorfoseiam (e vulgarizam, dramatizando-o em analogia com os "casos" do dia-a-dia e da crônica policial noticiados nos jornais - em francês, faits divers), gerando um "paradoxo do evento": o próprio deslocamento da mensagem narrativa em direção a suas virtualidades imaginárias, espetaculares, parasitárias, permitiria ao historiador do estritamente contemporâneo inserir os eventos numa série. Em lugar, porém, de procurar reduzir o evento, ele culminaria neste, fazendo conscientemente surgir o passado, o espessor histórico, as estruturas, em lugar de fazer incons-

1 AUGE, Marc. Non-places. Introduction to an anthropology of supermodernity. Trad. de John Howe. London/New York: Verso, 1995, p. 7-41. 
cientemente surgir o presente no passado (ou seja, projetar o presente no passado). Em outras palavras, os eventos permitiriam evidenciar o sistema. ${ }^{2}$

Nos casos de Nora e Augé com que começamos, as reflexões se restringem, portanto, ao mundo estritamente contemporâneo. Acontece, porém, que muitos historiadores encararam o "retorno do evento" como algo muito mais geral, aplicável por exemplo à história de qualquer época.

Em tal contexto, alguns entenderam a "volta do acontecimento" como uma oportunidade de desconstrução da história política e seus objetos. Um bom exemplo é o historiador norte-americano (especialista na história da França) Theodore Zeldin, já na década de 1970. Seu alvo principal foi o conceito de nação ou, mais exatamente, de identidade nacional francesa. Segundo Zeldin, não existe identidade nacional, a não ser como uma construção: nossos instintos nos dizem que há algo diferente entre um alemão e um italiano; mas também nos dizem que a terra é plana. A desconstrução da idéia de nação seria libertadora para o historiador, livrando-o de várias distorções: a ênfase no político e não no social, no público e não no privado, na alta cultura e não na cultura popular, nos homens e não nas mulheres, nos adultos e não nos jovens, nas classes e outros grupos e não nos indivíduos. Para conseguir isto, acha o autor que é preciso separar os "eventos" da "cola" que os historiadores impuseram aos mesmos. Entende por "cola" as categorias e conceitos que os intelectuais somaram aos eventos para construir uma ilusória noção de sentido e ordem e aplicá-la a uma vida que na verdade é quotidiana e caótica. A estratégia para tanto seria um método pointilliste que se assemelhe ao que os impressionistas faziam em pintura. Acha que, como resultado, ocorreria a redução das complexidades e tiranias da história (causalidade, cronologia, classe, nacionalidade) às formas elementares - a irredutivel realidade diferencial dos indivíduos.

Gertrude Himmelfarb, criticando a empresa de Zeldin, duvida de que tenha conseguido em sua própria obra fazer o que prega, citando frases do autor como as seguintes: "Naturalmente, ele não é o típico operário francês". "Na França, deve-se não somente comer e beber, mas sim, também falar". "Nenhum estrangeiro deveria zombar da língua francesa, primeiro porque não a entende direito, em segundo lugar porque ela tem status divino na França”. Na verdade, o ataque do autor à idéia de identidade nacional parece partir do

2 NORA, Pierre. "Le retour de l'événement". In: LE GOFF, Jacques e NORA, Pierre (orgs.). Faire de l'histoire. I. Nouveaux problèmes. Paris: Gallimard, 1974, p. 210-230. 
princípio de que se trata de uma entidade imóvel, sem história, pura construção abstrata. Ora, como qualquer outra coisa, o que define uma nação muda no tempo, pelo qual não basta demonstrar ausências de certas características em determinados momentos do tempo para pretender que, por tal razão, inexista a identidade nacional. Zeldin também parece cair em outra falácia: a de que os que falam de nação e sentimento nacional supõem uma uniformidade, uma indiferenciação das pessoas que negue o regional, as idiossincrasias individuais, etc. - o que é obviamente falso. ${ }^{3}$

Este não foi o único caminho para tentar "desconstruir" a história política. Outro, talvez mais conhecido no Brasil, foi o de desviar a ênfase da politica para o poder e então, mediante algum tipo de construção do conceito de poder que negasse prioridade na análise ao poder estatal, propor "novos objetos", diferentes daqueles que ocupam a Ciência Política. Dentre tais tentativas, a mais famosa entre nós é provavelmente a de Foucault na Microfisica do poder. ${ }^{4}$ Por isto mesmo, não a tomarei como exemplo, mas sim, certos enfoques de base antropológica que "desviam" a própria noção de poder para longe das definições habituais centradas no poder politico.

Peter Wilson, em livro de 1988, parte da definição de Bertrand Russell, para quem o poder seria "a produção de efeitos pretendidos", e da de Steven Lukes, que acha que o poder reside, não na produção real de efeitos, mas sim, na capacidade de produzi-los: assim, seria preciso separar o poder factual do poder potencial ou virtual. Lukes também critica o termo "pretendidos", já que os efeitos do poder podem ser perfeitamente inintencionais. Quanto a Wilson, propõe tomar a palavra "efeitos", não - como pretendia sem dúvida Russell como conseqüências de natureza material, observáveis, eventualmente quantificáveis; mas sim, num sentido menos sensível ou físico, mas não menos real: "efeito" entendido como "impressão". Assim, o poder pode consistir em dar a outras pessoas, através de certas ações, a impressão de ser capaz de fazer algo, sem de fato fazê-lo. Baudrillard já havia dito que o poder é uma simulação em perspectiva de si mesmo. Isto abre a porta a um estudo do poder como espetáculo, como ritual, no sentido de transmitir a idéia de que se possui a capacidade de produzir outros efeitos mais materiais, sem ter no entanto de

3 A exposição de algumas das idéias de Theodore Zeldin e a crítica delas baseou-se em: HIMMELFARB, Gertrude. The New History and the old. Critical essays and reappraisals. Cambridge (Mass.): The Belknap Press, 1987, capitulo 7, p. 121-142: "Is national history obsolete?"

4 Cf. FOUCAULT, Michel. Microfisica do poder. 2. ed. Trad. de Roberto Machado. Rio de Janeiro: Graal, 1981. 
o fazer de fato. Por isto mesmo, Wilson opõe as "surrealidades" do poder - em que se concentra - às suas "realidades".

Cita, a seguir, a opinião de Hannah Arendt de que o poder se definiria como "a habilidade humana não só de agir, mas de agir em concerto". Ou seja, o poder é um poder das pessoas umas em relação às outras, é uma ação conjunta ou grupal: não uma função, como em Russell, mas uma maneira de ser, dependente da unidade de um grupo. Habermas criticou a opinião de Arendt como sendo uma volta à noção de "contrato social", de "lei natural", o que explicaria o fato de a autora voltar sempre à questão da pólis grega: um ângulo que purifica a política de conflitos econômico-sociais e da necessidade de administrá-los. Para Wilson, o valor da definição de Arendt consiste em apontar para o fato de que indivíduos, isolados quanto a outros aspectos, quando agindo em grupo, em uníssono, se tornam uma fonte de poder e de sua eventual delegação. Mas, como decide um grupo a quem delegar o poder? Wilson considera, quanto a isto, que uma pessoa precisa de certo modo já estar "no poder" antes de ver-se delegar tal poder por um grupo - o que o conduz a considerações etnográficas a respeito do tipo de líder que exige a lealdade apresentando-se como fundador/ancestral do grupo, ou seu direto descendente. De novo, por este caminho, Wilson salienta o que chama de "poder surreal", em lugar de concentrar-se no "poder real". 5

\section{2 - HISTÓRIA POLÍTICA, APESAR DE TUDO: SEU DILEMA BÁSICO}

Acontece, porém, que as propostas que conduzem, por estes e outros caminhos, a uma dissolução dos objetos habituais da história política não são consensuais. Muito longe disto, a história política existe e é praticada por um número muito considerável de especialistas.

A análise dessa história política atualmente produzida mostra ainda vivo um dilema presente há muito tempo nesse tipo de história: em política, lidamos com sujeitos individuais ou transindividuais? Hoje, como no passado, as respostas a esta pergunta são variáveis. As teorias acerca das sociedades complexas costumam distribuir-se segundo duas posições polares: 1) teorias que enfatizam a integração social - que, num sentido bem genérico, podemos chamar de funcionalistas; 2) teorias que enfatizam o conflito social.

5 WILSON, Peter J. The domestication of the human species. New Haven/London: Yale University Press, 1988, capitulo 5, p. 117-150: "The surrealities of power". 
No primeiro caso, o ponto de partida é o fato de a sociedade ser vista como uma soma de indivíduos. Cada indivíduo, por sua vez, é um ser delimitado, unificado, integrado, livre e transparente a si mesmo: um sujeito de conhecimento e um centro dinâmico de consciência, emoção, ação e juizos. A complexidade, a estratificação social e o Estado teriam surgido das necessidades sociais. Os elementos básicos desta forma de pensar implicam que: 1) os interesses sociais são compartilhados, mais do que opostos; 2) no sistema social, predominam as vantagens comuns, mais do que o domínio e a exploração de uma minoria sobre uma maioria; 3 ) tal sistema se mantém mais pelo consenso do que pela repressão ou coerção; 4) as sociedades são sistemas integrados que evoluem lentamente, em lugar de mudar através de rupturas descontinuas (revoluções).

A integração social seria, pois, algo útil e legítimo. Se os administradores e outras pessoas de status alto vivem melhor e ficam com uma parte desproporcionalmente alta da renda social, trata-se de um custo necessário para que sejam possíveis os benefícios da integração social. Em outras palavras, a exploração social, se existe (e esta posição tenderá a negálo), é um custo normal da estratificação social, assim como a possibilidade de maus governos é um custo normal para que haja governo. Em qualquer caso, as disfunções sociais que surgirem deverão ser corrigidas, reformadas; a sociedade, tal como existe, deve ser preservada através de reformas pontuais, parciais, ela é um dado impossivel de mudar in totum num periodo curto. $O$ que existe é necessário e por isto existe. Entre os desta posição geral houve grande variedade de posturas e teorias: o único comum é uma espécie de filosofia global da política e da sociedade. Entre os mais notáveis proponentes de teorias temos Max Weber, Émile Durkheim, Talcott Parsons.

No segundo caso - o das teorias que enfatizam o conflito, a luta de classes -, o Estado teria surgido em função do aparecimento de interesses divididos na sociedade que se tornava complexa (tratar-se-ia da sociedade póstribal) e estaria baseado na dominação, na exploração, na coerção. Mais especificamente, as instituições governamentais de tipo estatal, fundamentadas no monopólio da força armada, na organização territorial, na cobrança de impostos, surgiram como mecanismos coercitivos e repressivos para resolver, em favor da posição privilegiada da classe dominante, os conflitos intrassocietais que emergiam por causa da estratificação econômica (proprietários/não-proprietários dos meios de produção mais importantes) e social. A classe dominante, para existir e manter-se como tal, explora e degrada as massas, a maioria da população. 
Neste caso, com frequiência, o sujeito social é visto como sujeito transindividual, coletivo: classes sociais, não indivíduos. Também aqui, podem existir consideráveis variações, apesar de uma filosofia geral similar. Entre os proponentes de peso estariam Karl Marx, Friedrich Engels, Antonio Gramsci, Gordon Childe, Leslie White, Morton Fried.

Salienta-se, nesta posição, o caráter histórico, instável, transitório das sociedades, mais do que o seu aspecto integrado, homeostático; e acredita-se na possibilidade de sua transformação radical (revolucionária) num período relativamente curto. ${ }^{6}$

Vou exemplificar as duas posições polares com um autor tomado como exemplo em cada uma, respectivamente Weber e Gramsci. Não estarei interessado, porém, nos conteúdos específicos das idéias políticas de ambos, mas sim nas premissas de base de seu pensamento político.

Sejam as seguintes passagens de Max Weber (ênfases minhas):

"A sociologia (...) é uma ciência que tenta um entendimento interpretativo da ação social com a finalidade de, assim, chegar a uma interpretação causal de seu curso e seus efeitos. Uma 'ação' é qualquer comportamento humano quando e na medida $\mathrm{em}$ que o individuo agente vincule a ele um significado subjetivo. (...). A ação é social na medida em que, em virtude do significado subjetivo a ela vinculado pelo individuo (ou individuos) agente (ou agentes), leve em conta o comportamento de outros e seja, por conseguinte, orientada em seu curso."7

"Poder é a probabilidade de que um ator no interior de uma relação social esteja numa posição que lhe permita impor a sua própria vontade a despeito de resistência, independentemente da base em que tal possibilidade repouse." 8

Fica evidente que, para Weber, a análise parte do nível individual e o privilegia. Isto é assim, coerentemente, em suas concepções acerca da política. Por exemplo, ao tratar do "conceito de partidos" (entenda-se: partidos políticos contemporâneos), as atividades deles são definidas, em certo ponto

6 Para uma sintese interessante das posições polares aludidas - embora tendendo, confessadamente, a apoiar no fim das contas a postura "funcionalista" ou "integracionista"-, ver: TAINTER, Joseph. The collapse of complex societies. Cambridge: Cambridge University Press, 1988, p. 33-37.

? WEBER, Max. The theory of social and economic organization. Trad. de A. M. Henderson e Talcott Parsons. New York: The Free Press; London: Collier-Macmillan, 1964, p. 88.

8 Idem, ibidem, p. 152. 
da análise, em termos dos "elementos" nelas envolvidos: 1) "líderes partidários" e seus assessores: tais líderes desempenham "o papel predominante"; 2) os "membros ativos do partido", que na maioria dos casos têm a função de "aclamar" os líderes, embora em certas circunstâncias possam agir mais ativamente (ações de controle, discussão, queixas, até mesmo de "iniciar revoluções dentro do partido"); 3) as "massas inativas de eleitores ou votantes": não passam de "objetos cujos votos são procurados na época das eleições", sendo suas atitudes importantes somente para orientar as formas de engajá-los que os líderes usarão, ou para atrai-los em detrimento de outro partido, havendo conflito pelo poder; 4) os "financiadores do partido", que usualmente - não sempre, porém - "permanecem ocultos", agindo nos bastidores. ${ }^{9}$ Como se pode notar, a prioridade nas iniciativas e $\mathrm{o}$ aspecto ativo é tanto mais importante quanto menor for a instância interveniente, máxima no caso dos "líderes", isto é, uns poucos indivíduos proeminentes; outrossim, cada instância coletiva na verdade se resolve em agregados de indivíduos em qualquer análise mais detalhada segundo o ponto de vista weberiano. conflito aparece como coisa eventual, como circunstância diferente da habitual.

No caso de Gramsci, o partido político "não passa de uma nomenclatura de classe", de modo que, em se tratando do partido revolucionário - aquele "que se propõe anular a divisão em classes" -, "sua perfeição e o cumprimento de sua finalidade consistem em ter deixado de existir por já não existirem classes, nem, portanto, as expressões destas".

É verdade, entretanto, que Gramsci vê de maneira bem mais nuançada do que a maioria dos pensadores marxistas a dialética do coletivo e do individual. Não nega que o indivíduo seja, em primeira aproximação, criatura das relações de classe, em que se insere mas que não cria. Defende, entretanto, uma aproximação radicalmente histórica a tal questão. No passado précapitalista, os líderes carismáticos tinham maior amplitude de ação, já que o "homem coletivo" só existia muito debilmente. No mundo moderno, entretanto, o "homem coletivo" tem bases concretas, materiais, criadas pelo próprio capitalismo. Ele pode ser, porém, coisas diferentes, resultando de um "conformismo imposto" autoritariamente ou de um "conformismo proposto" - em cujo caso já não se trata, na verdade, de conformismo, mas de consenso a partir de uma consciência crítica que rompe com o conformismo autoritário.

9 Idem, ibidem, p. 408-409. 
Do mesmo modo, "a luta contra o individualismo o é contra um individualismo determinado, que tem um determinado conteúdo social", e não, algo abstrato.

Gramsci é coerente com tais posições ao dizer que a pergunta mais correta a ser formulada filosoficamente não seria "o que é o homem?", e sim, "o que pode o homem chegar a ser?", os limites em que podemos ser "forjadores de nós mesmos". Uma tal questão, para o autor, levaria a conceber o homem "como uma série de relações ativas (um processo)". Nisto, "a individualidade tem a máxima importância", mas ocorre que "a humanidade que se reflexa em cada individualidade está composta de vários elementos: 1) o indivíduo; 2) os outros homens; 3) a natureza." A relação do indivíduo com os outros individuos e com a natureza é orgânica, não uma mera justaposição; e passa necessariamente pelo fato de pertencer a entidades transindividuais. "Se a individualidade própria é o conjunto destas relações, construir para si uma personalidade significa então adquirir consciência de tais relações; e modificar a personalidade significa modificar o conjunto dessas relações". ${ }^{10}$

\section{3 - O QUE É A HISTÓRIA POLÍTICA HOJE?}

Se o pós-estruturalismo tentou desconstruir a história política, a escola dos Annales e certos tipos de marxismo a haviam negligenciado ou a queriam tratar como um epifenômeno. Assim, quando Jacques Julliard se viu confiar a tarefa de "restaurar" a história política como opção respeitável pelos organizadores de Faire de l'histoire, em 1974, " e quando, de novo, um empreendimento similar the foi encomendado em 1982 pelos coordenadores do volume norte-americano The New History, ${ }^{12}$ começou por tratar de demonstrar a especificidade da politica como objeto. Existem problemas políticos que resistem às modificações da infra-estrutura e não se confundem com as correntes culturais que no momento prevaleçam. Além do mais, o

10 GRAMSCI, Antonio. Antologia. Seleção, tradução e notas de Manuel Sacristán. México: Siglo XXI, 1970, p. 281-283, 347-351, 353-354, 437-439.

11 JULLIARD, Jacques. "La politique". In: LE GOFF, Jacques e NORA, Pierre (orgs.). Op. cit. II. Nouvelles approches. Paris: Gallimard, 1974, p. 229-250.

12 JULLIARD, Jacques. "Political history in the 1980s: reflections on its present and future". In: RABB, Theodore K. e ROTBERG, Robert I. (orgs.). The New History. The 1980s and beyond. Princeton (New Jersey): Princeton University Press, 1982, p. 29-44. 
século XX assistiu a um acréscimo do papel da política nas sociedades. Domínios que no passado eram deixados à "natureza", a forças "espontâneas" - a economia (segundo a teoria liberal, sujeita a uma regulação "natural" pelo mercado), a demografia, até mesmo a cultura (no sentido de cultura intelectualizada) - passaram a ser objetos de políticas especificas. Mesmo sendo verdade que o sucesso de tais políticas nem sempre é muito claro, a verdade é que, na prática, o poder de Estado pesa, hoje em dia, sobre os cidadãos bem mais do que, por exemplo, o de Luís XIV e outros monarcas absolutos sobre seus súditos. Assim, é lógico que exista uma visibilidade maior dos fatos políticos no mundo contemporâneo, o que leva a querer estudá-los também em sociedades nas quais podiam ser bem menos visíveis.

Segundo Julliard, a renovação do campo da história política só poderia ocorrer através do contato com a Ciência Política e, achava, através de um abandono da curta duração como interesse exclusivo, adotando uma preocupação com a longa duração, ocupando-se com os fenômenos que indicam permanência além daqueles vinculados à mudança. Em suma, pregava uma transformação da história política bem dentro da tradição dos Annales: abertura às ciências sociais, longa duração, quantificação.

Também achava necessário, entretanto, nuançar as crenças dos annalistes acerca da relação estrutura/acontecimento, isto é, a crença em uma determinação que vai da estrutura para o acontecimento, nunca o contrário. $\mathrm{O}$ autor lembra, a respeito, um livro de Paul Bois sobre os camponeses do oeste da França que, segundo Emmanuel Le Roy Ladurie, mostra um acontecimento - a Revolução Francesa - gerando uma estrutura: a que sustenta a posição constantemente de direita dos camponeses ocidentais, em especial os do departamento de Sarthe (chouannerie), em função de terem sido desiludidos com a venda das terras nacionalizadas decidida pelos revolucionários - venda que não beneficiou aos camponeses, que não tinham os meios para adquirilas, e sim, à burguesia urbana. Mesmo contextualizando o evento estruturalmente, "o acontecimento passageiro secretou uma mentalidade duradoura: a curta duração secretou a longa duração".

No texto publicado em 1982, Julliard distinguiu vários tipos de história política.

Haveria, em primeiro lugar, a história politica como história narrativa, a qual no fundo se confunde com uma história narrativa tradicional, em que a política domina a exposição cronologicamente ordenada do que acontece às sociedades humanas. Trata-se de gênero que com freqüência imita a biografia, 
adotando metáforas biológicas de nascimento, crescimento, maturidade e morte.

Em seguida, a história política como um sistema explicativo. Neste caso, a política proporciona as principais hipóteses da explicação que se constrói. Assim, às vezes uma história centrada no parlamento parece dar conta do que vem acontecendo aos ingleses há vários séculos: a história coletiva parece derivar das expressões deliberadas das elites. Nesta ordem de idéias, variantes seriam trazidas por uma preocupação centrada na história das ideologias, por uma insistência nas motivações psicológicas dos líderes, etc. A perspectiva recente deste tipo de história política foi traçada, em livro coletivo coordenado por Peter Burke, por Richard Tuck. ${ }^{13}$

Em terceiro lugar, teríamos a história politica vista como uma sociologia histórica do poder, na linha por exemplo das análsies weberianas e seus tipos ideais: poder carismático, burocracia, etc. Através da descontinuidade, da tipologia e da comparação sistemática, sob a influência tanto da Sociologia quanto da Ciência Política, até certo ponto este tipo de história sacrifica a política, tal como se manifesta em fatos concretos, a uma tentativa de compreensão do significado subjacente a tais fatos. A estrutura do poder, as estratégias na perspectiva de uma teoria da decisão, a linguagem do poder, tornam-se mais importantes do que o estudo dos seus efeitos tais como tomam corpo nas ocorrências políticas específicas. Eis aí uma atitude que, no mesmo livro de 1982, o britânico Peter Clarke declararia "ilegítima" para os historiadores, os quais, por mais que possam aprender com a comparação e a teoria, para ele "estão de fato e em última instância preocupados com aquilo que só aconteceu uma vez". ${ }^{14}$ Ora, para quem se preocupa centralmente com o único e o irrepetível, as explicações causais, em história política especialmente, têm de aceitar o papel inelutável da contingência, daquilo que é trivial, que em certos casos supera em força causal as regularidades estruturais que interessam às ciências sociais.

Voltando à tipologia de Julliard, por último teriamos a história politica na longa duração. Tratar-se-ia, no fundo, de uma história da cultura política, em vinculação com o sistema de crenças e mais preocupada com as per-

13 TUCK, Richard. "History of political thought". In: BURKE, Peter (org.). New perspectives on historical writing. Cambridge: Polity Press, 1991, p. 193-205.

14 CLARKE, Peter. "Ideas and interests". In: RABB, Theodore K. e ROTBERG, Robert I. (orgs.). Op. cit., p. 45-47. 
sistências do que com as mudanças. Falando de regiões estruturalmente diferentes de um mesmo país mas com comportamentos políticos persistentemente divergentes, diz Julliard: "diante de estruturas sociais e econômicas comparáveis, a cultura é que faz a diferença" (posição para a qual se baseia em Maurice Agulhon). No estudo de uma determinada cultura política, seria importante levar em conta coisas como: 1) um evento formador (como aquele já indicado, relativo ao Sarthe francês); 2) os "círculos de pensamento" em que uma tradição de longa duração se elabora.

Concluindo esta parte, vamos referir-nos ao debate acerca da história política que está incluído num volume britânico coletivo preparado por Juliet Gardiner. ${ }^{15}$ Talvez convenha apontar que o mesmo livro contém um debate separado sobre a história militar que não será levado em conta aqui. Na discussão acerca da história política tomaram parte seis historiadores: T.P. Wiseman, G.R. Elton, Ronald Hutton, Roy Foster, John Turner e Kenneth O. Morgan.

Wiseman, um especialista na história da Roma antiga, defende uma perspectiva que lembra a segunda daquelas que lista Julliard. Diz que, em toda formação político-social, existem "cidadãos para os quais o peso, a despesa e o perigo do ativismo político são superados pelo espírito público, a tradição familiar, o desejo de riqueza e status, ou ainda por um impulso de pôr em movimento as coisas (e outras pessoas) - ou seja, pelo que de modo vago chamamos de busca do poder". A história política se concentra nestes líderes e quer averiguar como as coisas se passam: como conseguem eles eleger-se, como influenciam um conselho ou assembléia, que vantagens têm sobre os rivais, em que medida uma língua persuasiva ou uma presença carismática podem ser mais poderosas do que a riqueza, o patrocínio ou um corpo de seguidores fiéis.

Dito isto, as interpretações variam. No século XIX, os historiadores enxergavam na República Romana tardia um sistema de dois partidos - a nobilitas e os populares - onde, em nosso século, muitos preferem ver "facções" baseadas em famílias aristocráticas e seus aliados. Ambos os modelos pressupõem a cooperação em busca de finalidades comuns como a norma num corpo social onde a vida política e o ethos tradicional dos líderes dependiam da competição, da rivalidade. As alianças existiam, mas eram

15 GARDINER, Juliet (org.). What is history today? London: Macmillan, 1988, capitulo 2, p. 18 30: "What is political history?". 
temporárias e ad hoc. Havia assuntos específicos importantes que dividiam a elite política: mas nunca em algo nem de longe parecido com os partidos politicos contemporâneos. A história tem a ver "com casos particulares", portanto, a experiência romana "deveria ser interpretada em seus próprios termos".

Elton, um estudioso do período Tudor, acha que o objetivo da história política é, como sempre foi, "estudar a maneira em que grupos de seres humanos, durante os diferentes períodos, conseguiram organizar suas vidas coletivas e dirigir aqueles aspectos que determinam as relações no interior do grupo e com outros grupos externos". Isto é, a história política é a história dos seres humanos "na ação pública", no sentido de descrevê-la e explicá-la. Assim sendo, o historiador da política precisa: 1) analisar as leis, a constituição, a administração; 2) entender (quase sempre de segunda mão, através de uma bibliografia) os fenômenos sociais e econômicos; 3) ter uma boa idéia de como funcionam mentes, pensamentos, atitudes; 4) analisar as fontes da ação que visa a conseguir poder e responder aos interesses e suas exigências.

A história política lida com realidades e com pessoas, muitas vezes com indivíduos, não com abstrações estatísticas ou noções desencarnadas como as classes sociais: mas não cai na anedota, devido à moldura provida pela estrutura do governo e pelas relações dos agentes políticos uns com os outros. Diante de especialidades históricas que privilegiam uma temporalidade lenta, a história política provê um controle que impede que a história deixe de ser história, dota-a de uma estrutura do tempo móvel. Para fazê-lo, deve sem dúvida utilizar os achados das outras formas de fazer história, sem nunca perder de vista pessoas reais em circunstâncias reais e sempre passíveis de mutações.

Quanto a Hutton (que se ocupa com o século XVII), define a história política como a "organização e ação do poder em sociedades passadas". Ela tem um efeito democratizador, ao pôr a descoberto os pensamentos e ações dos governantes diante dos descendentes daqueles a eles subordinados. Sua dificuldade consiste em que usualmente as conseqüências das decisões políticas estão mais bem documentadas do que as próprias decisões. Ao mesmo tempo, trata-se da mais multiforme e menos auto-suficiente das variedades da história. A variação possível das instituições políticas humanas e das reações individuais às exigências da manutenção do poder são limitadas: o que muda constantemente é o contexto ideológico do comportamento, que 
depende por sua vez da evolução da moral, da tecnologia, da educação, da religião, dos padrões de riqueza e das relações internacionais. Sendo a política a arte do possivel, a história política, atenta ao anterior, tem de determinar o que era ou parecia possível em dada época aos participantes no jogo político. A preocupação político-institucional anterior dos historiadores da política tem mudado, nas ủltimas dẻcadas, a favor da atenção às maneiras em que a política se relaciona com outras formas de atividade numa sociedade dada. Os historiadores políticos agora se interessam por coisas como a demografia, preços e aluguéis, a natureza da cultura de corte ou da cultura popular.

O confronto resultante da atividade política com outras esferas de ação acabou resultando num reforço da crença em sua importância: as tentativas de representar a guerra civil inglesa do século XVII como um conflito social fracassaram, os estudos regionais da Reforma na Inglaterra mostraram a que ponto a mudança religiosa dependia da política do governo central, a guerra a mais dramática forma de política - agora é reconhecida como fator importante na mudança econômico-social, etc. Assim, se bem que a vida política não seja dissociável de seu contexto, ela muitas vezes possui um impulso e uma lógica próprios, que alteram o próprio contexto.

Foster, especialista da história irlandesa, acha que "a história política precisa ser escrita como a recriação de uma cultura política", o que exige uma "ênfase naquilo que as pessoas pensavam que estavam fazendo e nas razões pelas quais o queriam fazer, tanto quanto no resultado real (muitas vezes não pretendido) de suas ações." Assim, os historiadores da política deveriam concentrar-se nas intenções e preocupações dos políticos, tanto quanto nos eventos da política. E isto, tanto em estudos da política "popular" quanto naqueles da política parlamentar. A cultura política é algo complexo, denso, rico e estável demais para ser reduzida a uma mera superestrutura. Ao mesmo tempo, o conhecimento das contingências não tem por que negar a relevância de padrões mais vastos.

Turner, pesquisador das relações dos homens de negócios com a política, acha que a história politica se dirige a saber como se obtém e usa o poder na sociedade. Na sua maioria, os historiadores da política contemporânea enfatizam o "como" e se fixam nos partidos políticos, na política partidária. O Estado é o foco mais visivel do poder e os políticos, na Grã-Bretanha, há dois séculos o vêm controlando através de partidos. Por sua vez, a história partidária percebe pólos: o mais alto é o dos "cinqüenta ou sessenta políticos em tensão consciente uns com os outros cuja autoridade admitida constitui a 
liderança política"; o mais baixo tem a ver com coisas como o comportamento eleitoral estudado numa escala local, por exemplo, ou com a política ligada aos sindicatos. No entanto, existe tensão entre os historiadores da "alta" e da "baixa" política. As biografias de políticos da elite tendem a ver a história política pelos olhos dos líderes do parlamento. A história política "vista de baixo" tende a ignorar o parlamento: ora, como entender, sem levar em conta o mundo mental parlamentar e da burocracia de Estado, o reformismo da politica dos trabalhistas britânicos no século XX?

É óbvio, outrossim, que os partidos não esgotam a questão do poder na sociedade: existe o poder do patrão sobre o empregado, do homem sobre a mulher, etc. Mas, mesmo deixando de lado este aspecto da questão, há assuntos (como por exemplo a política em tempo de guerra) para os quais os partidos são pouco relevantes. Isto pode obrigar a que se considerem contextos sociais amplos. Assim, por exemplo, ao conduzir a guerra em 1917, os lideres britânicos como Balfour tinham diante de si o que acontecera na Rússia e temiam que a classe operária de seu próprio país se revoltasse contra o esforço de guerra e destruísse, como na Rússia, o sistema vigente. Assim, era preciso atrair os populares para o esforço de guerra e, ao mesmo tempo, usar a criação do Ministério da Saúde e os inícios de um programa de habitação popular como meios para disputar o apoio deles com o movimento operário. A intervenção governamental nas relações industriais não queria só proteger o esforço de guerra, mas sim, também, a estrutura vigente de propriedade privada. Tudo isto é política e, portanto, tema para a história política.

Por fim, Morgan - compilador da The Oxford illustrated history of Britain (1984) - pensa que a pesquisa em história política responde à pergunta: "Em que reside o poder em qualquer sociedade dada, que equilíbrio de forças afeta sua ação e como pode ser entendida a sua natureza?" Limitar a política às atividades, vistas endogenamente, de uma pequena elite de governantes operando à base da retórica e da manobra leva à eliminação do exame das mudanças nas políticas e programas perseguidos, das vinculações do papel dos ministros, burocratas partidários e funcionários públicos com a comunidade social ampla de que fazem parte. Outrossim, a história política deve transcender a biografia: ela tem a ver é com grupos, padrões, harmonias e conflitos coletivos, continuidades e rupturas. A história administrativa não tem como abordar questões da maior importância, como a mobilização do poder e sua tradução na tomada de decisões. A história política consiste em estudar, para qualquer corte do objeto social, como o poder é buscado, 
exercido, desafiado, abusado e negado. Isto implica a abertura do historiador da política à interação, em dados momentos ou conjunturas, de enorme variedade de forças políticas, sociais, econômicas, culturais e psicológicas, bem como o uso de materiais documentais extremamente variados, em especial para a história contemporânea. E a história política não deve ser exageradamente racionalista: é preciso não esquecer as pressões da época e das circunstâncias que inexoravelmente deram forma às reações de políticos acossados por elas. Eles não estavam interessados em proclamar verdades válidas universalmente, e sim, em apaziguar, administrar, empurrar com a barriga; ao fazê-lo, iam relacionando como fosse possível seus princípios com as realidades que encontrassem.

\section{CONCLUSÃO}

Serão as posições examinadas representativas? Acho que sim, embora eu sem dúvida não tenha tentado englobar na análise todas as tendências existentes: para um bom panorama delas, recomendo um texto recente do Professor Francisco Falcon. ${ }^{16}$

Caso sejam, como creio, representativas, delineiam - além das tentativas de "desconstrução" pós-estruturalistas e pós-modernas, de influência limitada em história política - um panorama predominantemente conservador do ponto de vista das concepções políticas envolvidas. É óbvio, por outro lado, que a história política abandonou as ingenuidades do narrativismo tradicional em favor de posições mais de acordo com a moderna Ciência Política na imensa maioria dos casos. E ela procedeu ao seu aggiornamento no interior dos estudos históricos vistos em conjunto.

Julliard, saudado como líder da renovação da história política na França, nos Estados Unidos e entre nós, escreve coisas como a seguinte (no artigo já mencionado de 1982):

"Num país democrático, a arte de governar pode ser sintetizada como uma arbitragem permanente entre o desejo de tomar a melhor - que não é sempre a mais popular - decisão em termos dos interesses do país e a tentação de tomar a decisão que favorecerá mais a reeleição dos lideres."17

16 FALCON, Francisco. "História e poder". In: CARDOSO, Ciro Flamarion e VAINFAS, Ronaldo (orgs.). Dominios da História. Rio de Janeiro: Campus, 1997, p. 61-89.

17 JULLIARD, Jacques. "Political history in the 1980s: a view on its present and future", já citado, p. 35 . 
A passagem parece confundir "a melhor decisão em termos dos interesses do país" com a melhor decisão que os lideres politicos acham ou alegam ser a melhor para o país. Não é o mesmo, de jeito nenhum, nem é uma mera nuance! E, se a "melhor decisão" - que a elite iluminada constituída pelos "líderes" aparentemente sempre conhece - não for "a mais popular", inferir-se-ia que em tais casos "o povo" está errado, equivocado? No tocante ao dilema indicado na frase de Julliard, o melhor seria acaso que os líderes deixassem de populismos e impusessem a "melhor decisão para o país"?

Estavam errados os franceses que recentemente foram às ruas aos milhões na defesa de direitos e conquistas que lhes queriam retirar? Posteriormente, tais franceses reconduziram os socialistas ao poder, desautorizando o projeto direitista para a França. Quando estiveram "certos": ao eleger a direita, ao eleger a esquerda, ou em ambos os casos? Note-se que, se há "decisões" certas ou adequadas em si para uma dada época, a terceira possibilidade parece dificil de sustentar. Deveríamos, acaso, acreditar nos cientistas políticos socialmente conservadores (não importa se politicamente "liberais") que defendem uma democracia representativa absolutizada contra a de participação direta, no sentido de que o povo só deve ser chamado de vez em quando para delegar pelo voto o poder a representantes seus, mas, a seguir, faria melhor em abandonar a política nas mãos dos especialistas - políticos e tecnocratas - e deixar de nela se imiscuir? ${ }^{18}$ A pergunta não é vã: afinal, desde 1974 - conhecendo um auge em 1989 - os esforços consideráveis empreendidos na desconstrução de objetos históricos como a Revolução Francesa, transformada em "festa", "ritual", vista "nos menus dos restaurantes", etc. mas descaracterizada como revolução social - certamente não são política ou ideologicamente inocentes.

É verdade que Julliard fala com freqüência na democracia, sempre ameaçada pelas posições totalitárias, às vezes citando em apoio disto... Hannah Arendt (cuja trajetória de vida, aliás, numa discussão assim the daria autoridade no mínimo discutivel, em minha opinião, digam o que disserem os seus fãs estrangeiros ou nacionais). As inclinações políticas do autor francês parecem conter contradições muito dificeis de resolver, as quais não deixaram de transparecer num artigo programático.

18 Ver uma interessante discussão a respeito em: FINLEY, Moses I. Vieja y nueva democracia. Trad. de Antonio Pérez-Ramos. Barcelona: Ariel, 1980, capitulo 1, p. 9-48: "Dirigentes y dirigidos". 
O marxismo, que exerceu a máxima liderança neste século sobre o pensamento mais à esquerda, pelo próprio fato de insistir na vinculação inseparável entre teoria e práxis, está em franca perda de hegemonia em função das derrotas políticas dos partidos, tendências e regimes que, com ou sem razão, falavam em seu nome. Os debates a respeito, em especial no tocante à teoria marxista do Estado e à história política numa interpretação marxista, na sua maioria chegam a conclusões negativas. O que não quer dizer, é claro, que o seu dossiê esteja encerrado em definitivo. Afinal, há poucas coisas tão ou mais inteligentes e instigantes disponíveis acerca da política e da história politica do que os escritos de Antonio Gramsci. ${ }^{19}$

19 Ver, por exemplo: BOBBIO, Norberto et al. O marxismo e o Estado. Trad. de Federica L. Boccardo e Renée Levie. Rio de Janeiro: Graal, 1979; McCARNEY, Joseph. Social theory and the crisis of Marxism. London e New York: Verso, 1990; HERRA, Rafael Ángel (org.). Sobrevivirá el marxismo? San José (Costa Rica): Editorial de la Universidad de Costa Rica, 1991. 